\title{
Ultrastructure of Calcified Cartilage in the Endoskeletal Tesserae of Sharks
}

NORMAN E. KEMP AND SANDRA K. WESTRIN

Division of Biological Sciences, Department of Experimental Biology, The University of Michigan, Ann Arbor, Michigan 48109

\begin{abstract}
The tesserate pattern of endoskeletal calcification has been investigated in jaws, gill arches, vertebral arches and fins of the sharks Carcharhinus menisorrah, Triaenodon obesus and Negaprion brevirostris by techniques of light and electron microscopy. Individual tesserae develop peripherally at the boundary between cartilage and perichondrium. An inner zone, the body, is composed of calcified cartilage containing viable chondrocytes separated by basophilic contour lines which have been called Liesegang waves or rings. The outer zone of tesserae, the cap, is composed of calcified tissue which appears to be produced by perichondrial fibroblasts more directly, i.e., without first differentiating as chondroblasts. Furthermore, the cap zone is penetrated by acidophilic Sharpey fibers of collagen. It is suggested that scleroblasts of the cap zone could be classified as osteoblasts. If so, the cap could be considered a thin veneer of bone atop the calcified cartilage of the body of a tessera. By scanning electron microscopy it was observed that outer and inner surfaces of tesserae differ in appearance. Calcospherites and hydroxyapatite crystals similar to those commonly seen on the surface of bone are present on the outer surface of the tessera adjacent to the perichondrium. On the inner surface adjoining hyaline cartilage, however, calcospherites of variable size are the predominant surface feature. Transmission electron microscopy shows calcification in close association with coarse collagen fibrils on the outer side of a tessera, but such fibrils are absent from the cartilaginous matrix along the under side of tesserae. Calcified cartilage as a tissue type in the endoskeleton of sharks is a primitive vertebrate characteristic. Calcification in the tesserate pattern occurring in modern Chondrichthyes may be derived from an ancestral pattern of a continuous bed of calcified cartilage underlying a layer of perichondral bone, as theorized by Ørvig ('51); or the tesserate pattern in these fish may itself be primitive.
\end{abstract}

Endoskeletal tesserae (Applegate, '67; Kemp et al., '75; Kemp, '77) or Kalkplättchen (Roth, '11; Weidenreich, '30; Bargmann, '39; Schmidt, '52) are blocks of calcified tissue which contribute rigidity to the cartilaginous skeleton of elasmobranchs and holocephalans. According to Applegate ('67), tesserae in sharks may occur in the chondrocranium, jaws and visceral arches, in the supporting cartilages of fins and clasper spurs, and in the neural or hemal arches and centra of vertebrae. There is evidence that the mineral component of shark skeletons is hydroxyapatite as in the bone, dentine, calcified cartilage and enamel of vertebrates generally (Kyle, '27; Urist, '61; Applegate, '67). Orvig ('51, '67) classifies tesserae as the second of three principal kinds of calcified cartilage in elasmobranchs: (1) globular calcification, considered to be an early stage of mineralization both ontogenetically and phylogenetically; (2) prismatic or granular calcification, the type which forms the tesserae; and (3) areolar calcification, occurring in the vertebral centra of Euselachii.

The term tesserae (var. tessellae) is also used in reference to small plates of dermal armor in fossil ostracoderms and placoderms 
(Tarlo, '67; Westoll, '67; Halstead, '73, '74), but this connotation does not apply to the integument of extant elasmobranchs. Moss ('77) has recommended that use of the term tesserae be restricted to designation of fossil fish dermal bone tissue "to avoid unnecessary confusion between dermal skeleton and calcified cartilage." Because the term is descriptive and has a long history of usage by paleontologists and histologists (Woodward, 1889; Ridewood, '21; Wurmbach, '32; Ørvig, '51; Schmidt, '52; Applegate, '67), however, we are using it with the explicit understanding that in this paper we will be considering only endoskeletal calcification in sharks.

Comparative anatomists have generally emphasized the cartilaginous nature of the endoskeleton in the Chondrichthyes, while recognizing that it may be partly calcified. Thus Daniel ('34) wrote that in elasmobranchs the endoskeleton "is formed of cartilage and never of bone, yet this cartilage differs greatly as to its rigidity.... In certain forms elastic fibers may also be included in the cartilage and calcification is present in many elasmobranchs." Similarly, Romer ('45) declared, "In the Chondrichthyes bone is utterly absent. The internal skeleton is purely cartilaginous. These structures are in many cases, calcified, but they never show true bone structure." Investigating the development of calcification in the skeleton of the dogfish Squalus acanthias, Benzer ('44) found that calcification progressed peripherally in centers of chondrification, not randomly but in a "specific and constant pattern." Although the basal plates of shark dermal denticles and teeth may be classified as acellular bone (Moss, '64, '68b, '70), calcified endoskeletal tissue in sharks is usually regarded as calcified cartilage (Moss, '77).

Investigations on the ultrastructure of the mesodermal hard tissues, bone, dentine and calcified cartilage in vertebrates, have sought to reveal the relationships between scleroblasts, organic constituents of their mineralizing matrices, and deposition of hydroxyapatite crystallites. It is well known that hydroxyapatite is laid down in close association with collagen fibrils in bone and dentine (Glimcher and Krane, '68; Boyde and Hobdell, '69; Boyde and Reith, '69; Höhling et al., '71; Höhling et al., '74). It also appears that membrane-bound matrix vesicles containing phospholipids and enzymes characteristic of scleroblast membranes may be the site of initial precipitation of calcium phosphate and initiation of hydroxyapatite crystallization in calcifying cartilage, and possibly also in bone and dentine (Anderson, '69, '73; Bonucci, '70, '71; Peresz et al., '74; Thyberg, '74; Bonucci and Gherardi, '75; Wuthier, '75; Yanagisawa, '75). Extracellular calcification in the hard tissues may be preceded by intracellular accumulation of apatite deposits (Mathews, '72). Despite distinguishing histological characteristics of cells and matrices prior to mineralization, bone, dentine and calcified cartilage develop into tissues which are much alike with respect to size and distribution of hydroxyapatite crystallites among collagen fibrils. The crystallites in these hard tissues remain relatively small in comparison with those of enamel, which may develop within filamentous sheaths (Travis, '68) or tubular fibrils (Kemp and Park, '74) polymerized from enameline protein.

In the present paper we will describe ultrastructural features of shark tesserae and consider their significance in relation to the evolution of endoskeletal calcification in vertebrates.

\section{MATERIALS AND METHODS}

Endoskeletal tissue from three shark species was used in this study. Blocks of tissue which included gross sections of jaws, fins, gill arches or vertebrae were excised from a $60-\mathrm{cm}$ gray reef shark, Carcharhinus menisorrah, and from a $120 \mathrm{~cm}$ white-tipped shark, Triaenodon obesus, both of which were collected at Enewetak Atoll, Marshall Islands. Jaw and fin tissue was similarly excised from a 40-cm lemon shark, Negaprion brevirostris, collected at the Lerner Marine Laboratory, Bimini, Bahamas, and donated by Doctor I. Kaufman Arenberg. Blocks were preserved in 95\% alcohol, in Bouin's fixative, or in glutaraldehyde at concentrations of $6.25 \%$ (Enewetak specimens) or $5 \%$ (Bimini specimen) in $0.1 \mathrm{M}$ phosphate buffer at $\mathrm{pH}$ 7.4.

For light microscopy Bouin's-fixed tissue was dehydrated in a graded series of ethanols, cleared in amyl acetate, embedded in paraffin and sectioned at $10 \mu \mathrm{m}$. Sections mounted on glass slides were stained with hematoxylin and eosin or with Heidenhain's azan stain. For transmission electron microscopy glutaraldehyde-fixed tissue was washed with $0.1 \mathrm{M}$ phosphate buffer, $\mathrm{pH} 7.4$, and post-fixed with icecold $1 \% \mathrm{OsO}_{4}$ in $0.1 \mathrm{M}$ phosphate buffer at $\mathrm{pH}$ 7.4. After dehydration in a series of ethanols 
the tissue was cleared in propylene oxide and embedded in Epon 812 or in a mixture of Epon and Araldite. Thin sections were cut with a diamond knife on an LKB Ultratome and collected on 200-mesh Athene grids. Microscopy was performed with an RCA EMU-3E electron microscope operating at $50 \mathrm{Kv}$. For scanning electron microscopy, tissue fixed either in $95 \%$ alcohol or in glutaraldehyde was treated with sodium hypochlorite in commercial Clorox (Boyde, '72), used either full-strength or diluted to $50 \%$, in order to remove organic material and expose mineralizing surfaces of tesserae. Specimens were washed in running water, dehydrated with a series of ethanols and mounted with Duco cement on 1/2-inch aluminum stubs. After drying in air they were coated with gold in a sputtering apparatus at the College of Engineering Electron Microscopy Laboratory, and viewed there in a JEOL Scanning Electron Microscope, model JSMU3, operating in the secondary electron mode at $15 \mathrm{Kv}$. Micrographs were taken on 4- $\times 5$ inch Polaroid film, type $55 \mathrm{P} / \mathrm{N}$.

\section{RESULTS}

The external appearance of the tesserae on the surface of several endoskeletal structures, namely, neural and hemal arches of vertebrae, gill arches and jaw skeleton, is shown in figures 1-5. Freed of perichondrial connective tissue by Clorox treatment the tesserae are seen as a mosaic of closely fitted tiles covering the surface of the hyaline cartilage forming the core of the endoskeletal element. Lines of separation and rounded openings between tesserae in these preparations are regions where inter-tesseral connective tissue and hyaline cartilage have been removed by Clorox. Relatively wide separations such as those marked by arrows in figures 1,2 and 4 resulted as the tesserae were pulled apart by shrinkage of the underlying cartilage during dehydration. The wide gaps free of tesserae in figures 1 and 2 resulted from erosion by treatment with Clorox long enough to undermine tesserae and cause them to drop off.

Individual tesserae vary somewhat in size and shape but are irregularly polygonal in Carcharhinus menisorrah and Negaprion brevirostris (figs. 1-3, 5). They are much more variable in form in Triaenodon obesus (fig. 4), apparently because of a tendency for fusion of adjoining tesserae. Applegate ('67) has called attention to the variable shapes of tesserae in different genera and has noted that in
Notorhynchus they "tend to fuse with one another." Roth ('11) examined the pattern of the mosaic of tesserae in a wide variety of elasmobranchs and classified it as regular (regelmässig) or irregular (unregelmässig). His survey led him to conclude that irreg. ularity of the mosaic was characteristic of the more primitive sharks. In his terminology the pattern we have observed in Carcharhinus and Negaprion should be considered regular, whereas that in Triaenodon is irregular. Ridewood ('21) observed that tesserae of vertebral arches were commonly in the form of a mosaic, but sometimes occurred as a continuous crust. We have not observed zones of extensive continuous calcification in our specimens, but such continuities could result from progressive fusion of separate tesserae.

At higher magnifications (figs. 6-8) one observes that the outer surfaces of tesserae are very rough. Scanning electron micrographs show two distinctive features of the surface: (1) the presence of globular excrescences or calcospherites, like those classified by Ørvig ('51) as an early stage of mineralization; (2) the crystalline composition of the surface in the form of needle-like hydroxyapatite crystals like those of bone and dentine. With respect to both calcospheritic and crystalline appearance, the outer surfaces of tesserae are virtually indistinguishable from those of basal plates of shark's teeth we have examined by scanning electron microscopy (Kemp and Smith, '76).

Tesserae of the neural and hemal arches in the specimens we have studied (figs. 1,3 ) were thin plates, evidently representing an early stage in growth of calcified skeletal prisms. Those of the gill arch and jaw (figs. 2, 5, 6) were thicker blocks, about as deep as they were wide. Assuming that the tesserae are first laid down as thin plates, it can be inferred that these thicker tesserae are at a later stage of growth than those of the neural and hemal arches. How the tesserae expand in girth and thickness as the shark grows is an intriguing question. Calcification might proceed on all surfaces of the tesserae, enabling them to enlarge in all directions. Continued growth of cartilage either by interstitial growth through division of chondroblasts or appositional growth from the perichondrium would allow the skeletal element to grow while its calcified tesserae were also growing.

We have not determined precisely how the tesserae grow, but their surface morphology 
indicates that they expand in all directions, progressively adding mass on outer, inner and lateral surfaces as the skeleton grows. On the outer surface, normally adjacent to the perichondrium, calcospherites and the rough surface contour of packed crystallites (figs. 6-9) provide evidence that calcification is in progress. Shorn of its rough outer surface (fig. 9), a tessera looks flat as though cleaved in a plane. Evidently the tesserae become laminated as they thicken. Lateral views of tesserae (figs. 9, 10) provide further evidence of lamination. Holes in the laminar surface (fig. 9) presumably were occupied by cells in the living tissue. Although the tesserae abut against one another laterally, they remain partially separated by uncalcified cartilage and hence retain the potential for lateral expansion. The underside of a tessera, normally in direct contact with hyaline cartilage, looks quite different from the outer side. Inwardly the tessera is covered by an abundance of calcospherites of variable size (figs. 10-12). This pattern indicates that calcification is actively in progress, with small calcospherites proba. bly fusing with one another and with the underside of the prism during growth. Surface morphology is thus demonstrably different on outer, lateral and inner surfaces of tesserae, but these differences are compatible with the supposition that growth proceeds in all three directions. Further study of surface changes during tesseral growth is clearly needed.

\section{Histology}

\section{Light microscopy}

The relationships between tesserae of the jaw and the tissues around them may be visualized from figure 13. Between tesserae and teeth there are two principal layers of dense connective tissue. The upper one of these, which we will call the sub-odontal layer or tooth bed, contains many large collagen fibers which run toward the base of a tooth and penetrate into its bony matrix (fig. 14). These are anchoring fibers like the Sharpey's fibers of mammalian bone (Boyde and Jones, '68; Boyde and Hobdell, '69; Jones and Boyde, '74). Similarly, the inner layer of connective tissue, the supra-tesseral layer, contains large collagen fibers which may penetrate as anchoring fibers (Sharpey's fibers) into the outer portion of a tessera (figs. 13,15). Blood vessels course between sub-odontal and supratesseral layers of connective tissue, but branches directed inward toward the tesserae appear to be sparse.

In sections stained either with hematoxylin and eosin or with Heidenhain's azan stain, a well developed tessera appears to be composed of two zones, as previously described by Tretjakoff ('26). We will designate the outer zone as the cap and the inner zone as the body of the tessera. With hematoxylin and eosin the body stains bluish-purple, whereas the cap zone is pinkish-purple because of the abundance of eosinophilic collagen fibers in its matrix. With the azan triple stain the body stains chiefly blue, but the cap zone has a predominately pink or yellowish color intermixed with blue. Basal plates of calcified teeth have essentially the same staining properties as do the caps of tesserae.

Throughout the tesserae there are embedded cells. As observed by Tretjakoff ('26), cells (scleroblasts) of the inner zone or body tend to be round and those of the outer or cap zone tend to be spindle-shaped. Cells in the body are clearly chondrocytes trapped by calcification of cartilage during growth of the tessera. These cells are well separated by intercellular matrix and randomly distributed. Scleroblasts within the cap zone appear to be derived more directly from the perichondrium. They are packed closer together than those of the body zone and are sufficiently aligned that the cap zone appears somewhat lamellar. Toward the inner part of the cap zone the embedded cells may be rounded, but toward the surface they are more usually spindle-shaped with their long axes parallel to the surface. Embedded cells just beneath the perichondrium often look like the elongated fibroblasts within the perichondrium itself, although the embedded cells as a rule are noticeably larger than the perichondrial fibroblasts. The possibility that scleroblasts in the outer part of the cap zone may be classified as osteoblasts will be considered in the DISCUSSION.

A distinguishing feature of the body of the tessera is the presence of basophilic contour lines, which have been called Liesegang rings (Gebhardt, '14; Bargmann, '39; Weidenreich, ' 30 ; Orvig, '51). These lines course in the matrix of the calcified cartilage between chondrocytes, and are of ten concentric around the cells or around centers which are subcellular in size (fig. 16). Calcospherites with concentric rings are abundant in the hyaline cartilage just beneath the tesserae. It is obvious 
that these sites of globular calcification become fused to the tessera and contribute to its growth. Contour lines are not completely absent from the cap zone, although they are much less conspicuous there. There may be two or three such lines between the elongated cells of the cap zone, in contrast to the many lines between cells in the body zone. There are also contour lines in the matrix of the hyaline cartilage outside the tesserae. These are usually more widely spaced than those within the body of a tessera (fig. 16), but in some slides the wave length between lines appeared to be of about the same dimensions both in the hyaline cartilage and in the tesserae.

\section{Electron microscopy}

At the electron microscopic level of observation, the relationship between perichondrial matrix and underlying cartilage cells in an unmineralized region between tesserae of the jaw in a lemon shark is illustrated in figure 17. Immediately surrounding the chondrocytes in this figure is a mottled gray-staining matrix typical of hyaline cartilage. Presumably it is composed of fine collagen fibrils interspersed with proteoglycans, as is characteristic of uncalcified cartilage (Campo and Phillips, '73). Above the chondrocytes in figure $\mathbf{1 7}$ is a zone of perichondrial matrix containing abundant coarse collagen fibrils. It should be pointed out that the specimen which yielded the thin sections illustrated in figures $17-21$ was a relatively small $(40 \mathrm{~cm})$ lemon shark. Its jaw tesserae were thin enough to section readily with a diamond knife. Efforts to obtain similar intact sections of jaw tesserae from our larger specimens of Carcharhinus $(60 \mathrm{~cm})$ and Triaenodon $(120 \mathrm{~cm})$ have been unrewarding. Ease of sectioning was obviously advantageous, but our sections of the lemon shark have one important drawback. Although they show ultrastructural features of calcification in tesseral bodies, they show only the beginning of calcification of the cap zone beneath the perichondrium.

Mineralization of the matrix around a peripheral chondrocyte of a tessera and in the perichondrial matrix above it is illustrated in figure 18. A zone of uncalcified cartilage, the capsular zone, surrounds the chondrocyte. Outside this zone toward the interior of the tessera, the matrix is heavily calcified in the dense pattern characteristic of calcified cartilage. Calcification in the matrix toward the perichondrium, however, is proceeding in association with coarse collagen fibrils. Figure 19 shows two chondrocytes toward the outer surface of a tessera with a zone of coarse collagen fibrils extending between them. Calcification is confined to the region of coarse fibrils, and some of the masses of hydroxyapatite crystals are elongated in the direction of the accompanying fibrils. This type of mineralization whereby crystallites are oriented along coarse collagen fibrils is characteristic of vertebrate bone (Glimcher and Krane, '68). It is significant that this type of mineralization occurs only on the outer border of the tessera in the region which will contribute to the cap zone. Coarse collagen fibrils are absent along the underside of the tessera where calcification of cartilage is in progress. As calcification progresses around chondrocytes entrapped within a tessera, the capsular zone diminishes and may be completely replaced by calcified car. tilage (figs. 20, 21).

\section{DISCUSSION}

\section{Ossification and calcification}

According to distinctions introduced by Röse (1898), ossification refers to mineralization of "true bone," including bone and dentine; and calcification refers to mineralization of "false bone," including calcified ligaments and cartilage. Ørvig ('51, '67), however, concluded from the work of other investigators (e.g., Hasse, 1879; Weidenreich, '22, '23, '30; Kyle, '27) that "no quite sharp boundaries can be drawn between the principal kinds of mesodermal hard tissues," and thus that the above distinctions are meaningless. Moss ('64) uses both terms but defines biological calcification as "the deposition of a calcium salt in or on any vital tissue," and ossification as "calcification of histologically recognizable osseous tissue." Alcock ('72) uses the term calcification in the same broad sense. Bachra ('67) specifically defines tissue calcification as "biologic deposition of apatite."

Although vertebrate bone, dentine and calcified cartilage can be distinguished histologically, the form of the mineral constituent is similar in all these tissues. Evidence from chemical analysis, X-ray diffraction, polarization microscopy and electron microscopy indicates that in all the vertebrate mesodermal hard tissues, including those of elasmobranchs, small hydroxyapatite crystals are deposited in close association with col- 
lagen fibrils (Bormuth, '33; Schmidt, '52; Urist, '61; Glimcher and Krane, '68; Höhling et al., '71, '74; Mathews, '72; Halstead, '74; Urist et al., '74; Mathews, '75; Howell and Pita, '76).

Moss ('77) has pointed out that calcified cartilage in the shark differs in two obvious respects from the calcified cartilage which de. velops in the epiphyseal plate of mammalian long bones. In the first place, chondrocytes in calcifying regions of the shark's skeleton do not undergo the swelling observed in the zone of hypertrophy of the mammalian epiphyseal plate. Secondly, chondrocytes in shark calcifying cartilage "appear to be vital," in contrast to the degeneration and cytolysis which overtake the hypertrophied chondrocytes bordering the metaphysis of a mammalian long bone. We have observed both by light microscopy and electron microscopy that cells enclosed within tesserae do not become aligned, hypertrophied nor cytolyzed. Their nuclei and cytoplasmic organelles look like those of living cells (figs. 13-21). Even in some mammalian bones, cell dissolution is not a necessary accompaniment of hypertrophy and calcification during endochondral ossification. Silbermann and Frommer (74) have shown that the mandibular condyles of mice become calcified as chondrocytes hypertrophy, but the cells remain viable. What appears to be necessary for calcification of cartilage is that chondrocytes secrete products which render its uncalcified matrix calcifiable. Included among such products are enzymes and possibly matrix vesicles as discussed below.

\section{Matrix modification}

Calcification of tesserae proceeds in part by development of globular concretions called calcospherites (Ørvig, '51, '67) which fuse to the surface of the growing prisms. Similar globular sites of calcification have been observed at the mineralizing front of calcifying bone, dentine and calcifying cartilage in mammals (Boyde and Hobdell, '69; MacConaill, '73). The globular form of these calcospherites may result from the diffusion of matrixmodifying enzymes spreading into spherical zones either around scleroblasts or around matrix vesicles.

It has been hypothesized that mineralization in the mesodermal hard tissules occurs only after proteoglycans of the precursor matrix are removed by hydrolysis, and collagen fibrils are thereby exposed (Dziewiatkowski et al., '68; Matukas and Krikos, '68; Howell et al., '69; Pita et al., '70; Fleisch et al., '75; Lohmander and Hjerpe, '75; Shepard and Mitchell, '76). Enzymes known to be secreted by scleroblasts include hyaluronidase, pyrophosphatase and acid hydrolases of lysosomal origin (Kogayashi, '71). Pyrophosphate has been reported as an inhibitor of mineralization; hence it is believed that pyrophosphatase may act to remove the inhibitor (Fleisch and Bisaz, '64). Cathepsin D, a lysosomal acid endopeptidase, functions in matrix turnover in skeletal tissues, as do a variety of enzymes classified as acid proteinases, thiol proteinases, neutral proteinases including cartilage proteoglycan degradation enzymes (CPGases), glycosidases, and miscellaneous enzymes including peptidases and sulphatases (Dingle, '73). Kuettner et al. ('75) have investigated the roles of the neutral proteinase lysozyme and a protease inhibitor in the replacement of cartilage by bone. Majeska and Wuthier ('75) have identified alkaline phosphatase, pyrophosphatase and ATPase in a fraction of limb epiphyseal cartilage consisting of isolated matrix vesicles. Information on the chemistry of shark skeletal tissues is available (Urist, '61; Mathews, '66, '68, '75), but specific knowledge about the enzymes which modify shark skeletal cartilage for cal. cification is limited.

Studies on matrix vesicles (Anderson, '69, '73) or "calcifying globules" (Bonucci, '70, '71) have implicated these structures as the initial sites of precipitation of calcium phosphate in the matrix of hard tissues (Ali and Evans, '73; Simon et al., '73; Thyberg, '74; Peresz et al., '74; Bonucci and Gherardi, '75; Wuthier, '75; Yanagisawa, '75). Amorphous calcium phosphate deposited within the vesicles may begin to crystallize as hydroxyapatite, followed by accumulation of crystallites in a radial pattern as membrane vesicles rupture (Sayegh et al., '74). These initial steps in calcification are then followed by crystallization of hydroxyapatite within and along collagen fibrils, according to those who consider matrix vesicles the initial sites of calcification. We have not confirmed that matrix vesicles initiate calcification of the matrix around endoskeletal tesserae, but a more detailed developmental study should be made.

Periodic precipitations called Liesegang rings were first described by Liesegang in 
1896; theories to explain them have included the processes of supersaturation, adsorption, coagulation and diffusion (Hartman, '47). The basophilic lines likened to Liesegang rings by Gebhardt ('14) develop within globular sites of calcification bordering tesserae and also within the bodies of the tesserae. As the globules fuse to the surface of the tessera, the rings around them become incorporated into the pattern of contour lines which run between the embedded cells throughout the body of the tessera (Weidenreich, '22; Bargmann, '39; Orvig, '51). The significance of these rings and contour lines in shark tesserae has not been elucidated. They might result from periodic secretion of enzymes or other cell products which diffuse away from chondrocytes and precipitate sequentially after these cells become functional as scleroblasts. Orvig ('51) ascribes them to "the rhythmic precipitation of lime salts within the ground substance." A more likely explanation in our opinion is that the basophilic lines result from modification of a normally laminate pattern of deposition of matrix constituents around and between chondroblasts. There is, in fact, a wave-like pattern in the matrix of uncalcified cartilage (fig. 16). Removal of proteoglycans and the resultant stainability of layered basophilic constituents, including collagen, already built into the structure of the matrix might account for the observed pattern of rings and lines in the tesserae. Either explanation - precipitation of secreted products or unmasking of a pre-existing wave pattern in the matrix - is speculative at present.

\section{Calcified cartilage and bone}

The fact that endoskeletal calcification remains tesserate throughout life is one of the features which distinguishes elasmobranchs and holocephalans from teleosts and higher vertebrates. The tesserate pattern of discontinuous calcified prisms separated by uncalcified cartilage provides three obvious advantages for the skeletal system: support, flexibility and the opportunity for growth without continuous remodeling. The pattern of continuous calcification within the calcified zones of a bony skeleton, on the other hand, may provide greater strength but permits less flexibility and less freedom for growth without turnover of mineral. Applegate ('67) has reported that turnover of mineral apparently does occur in tesserae, but
Moss ('77) has reminded us that turnover of mineral probably became more extensive after the evolution of the parathyroid glands in Amphibia.

We have shown that the tesserae in Carcharhinus menisorrah are not homogeneous blocks of calcified cartilage. Sections of decalcified specimens reveal that tesserae develop with inner and outer zones, which we have called respectively the body and cap. Tretjakoff ('26) described these zones in the calcified plates (verkalkten Platten) of neural and hemal arches of vertebrae in the skate Raja clavata. He reported that the outer zones of these plates contained spindle-shaped cells, and also that this outer layer was penetrated by collagen fiber bundles which he described as radial struts. Wurmbach ('32) studied the development of vertebrae in several shark species, Acanthias vulgaris, Galeus canis, Scyllium canicula and Pristiuris melano. stomus, and found that the tesserae of neural and hemal arches came in contact with one another as they grew but that they did not fuse. He noted also that cells and fibrils were oriented parallel to the surface in the outer zone of tesserae as animals grew older.

Orvig ('51) refers to "the more or less bonelike hard tissues" described by Wurmbach ('32) in vertebral arcualia and cites the opinions of some earlier investigators that pelvic fin claspers in male elasmobranchs and head claspers in chimaeroids are lined with a bony tissue. Although the hard tissue of claspers may contain blood vessels and is frequently pierced by calcified or uncalcified Sharpey fibers, Orvig ('51) concludes that this is not true bone but "some kind of calcified fibrous cartilage." In his opinion elamobranchs "are practically without true bone tissue in their endoskeleton." The presence of an outer zone different from the inner zone of tesserae and other endoskeletal structures in elasmobranchs is thus well documented, but interpretations of its histological identification differ. Orvig ('51) and others have demonstrated that certain Acanthodii also possessed a subperichondral hard tissue pierced by Sharpey fibers and containing fusiform cell spaces with canaliculi, features which Orvig considers justification for classifying it as "a bone tissue of a comparatively little differentiated type."

Our interpretation of the development of tesserae is that they originate as calcified car- 
tilage. Early plates in the jaw skeleton appear to be entirely surrounded by hyaline cartilage. Sometimes one observes sites of tessera formation deep within the interior of the jaw cartilage, and we have observed them deep within the interior of radial cartilages of the anterodorsal fin in Negaprion brevirostris as well as in the radial cartilages of the pectoral fin of the stingray Dasyatis americanus. Apparently chondrocytes function as scleroblasts in these intra-chondral sites of tessera formation, although this supposition has not been proven. As tesserae grow toward the surface of a skeletal element the zone of calcification reaches the perichondrium. Now calcification may proceed directly in the matrix of perichondrial fibroblasts without the delay resulting from appositional transformation of fibroblasts to chondroblasts. Therefore a calcified matrix develops around well differentiated collagen fibrils and fibers (Sharpey's fibers). Direct scleroblastic activity of inner perichondrial connective tissue cells could qualify them to be classified as osteoblasts rather than chondroblasts. Their activity produces a cap zone surmounting the earlier base of calcified cartilage. Histologically the tesseral cap could be considered a type of bone containing fusiform osteoblasts. Thus the tesserae may be interpreted as blocks of calcified cartilage which in their later stages are surmounted by a thin veneer of bone.

The tesserate pattern of endoskeletal calcification in sharks does not per se negate the presence of bone, for it is now commonly accepted that the separated basal plates of elasmobranch teeth are composed of acellular bone (Weidenreich, '22; Moss, '68b, '70; Hall, '75). One could interpret the tesseral caps as discontinuous bony elements affixed to their bases of calcified cartilage. On the assumption though that the shark endoskeleton does lack bone, Moss ('77) has suggested that there are epigenetic factors in shark cartilage or perichondrial tissues which may be "capable of regulating the shark scleroblasts to inhibit an osteoblastic differentiation, which these same cells are potentially capable of undergoing." It might be, for example, that the matrix of hyaline cartilage underlying inner perichondrial cells inhibits them from osteoblastic differentiation, but that this inhibition is lifted after the subperichondrial matrix becomes calcified. It has been demonstrated experimentally that fibroblasts may transform either to chondroblasts or osteoblasts depend- ing on their microenvironment (Bassett, '64; Hall, '75). Conditions which favor development of collagen fibers may be conducive to osteogenesis, while conditions leading to the predominance of mucopolysaccharide synthesis may favor chondrogenesis (Hall, '75). Progenitor cells from the proliferative zone of epiphyseal cartilage from rat metacarpals could transform to osteoblasts when transplanted intracerebrally (Meikle, '75). Experimental studies designed to test the potentialities of cartilage and perichondrial cells in elasmobranchs would be welcome.

\section{Evolution of endoskeletal tesserae}

Is the tesserate pattern of endochondral calcification primitive, or has it been derived from a more primitive bony pattern of calcification? Paleontological evidence that bone was already present in the skeletons of the earliest vertebrates, the ostracoderms, led to a reversal of the old idea that cartilage was the most primitive vertebrate skeletal tissue (Berrill, '55). Bone came to be regarded as the more primitive adult skeletal tissue, a concept which led Romer ('45) to speculate that "cartilaginous vertebrates are thus reasonably regarded as degenerate forms which fail to mature in skeletal development and exhibit as adults an immature cartilaginous condition of the skeleton." In accordance with this view is the speculation that the ancestors of modern sharks could form endoskeletal bone but their contemporary survivors have lost that ability (Moss, '77). In a dissenting opinion, Berrill ('55) has questioned the concept (Romer, '42) that cartilage should be considered solely an embryonic tissue adapted for growth. In his words, "the conclusion that cartilage could never have been an important component of a fully adult vertebrate skeleton I believe is unjustified."

Most discussion on the evolution of the endoskeleton has focused on the relative antiquity of cartilage and bone, often ignoring the significance of calcified cartilage as a connecting link. Orvig ('51) has reviewed evidence indicating that bone, dentine and globular calcified cartilage are "equally old formations." This concept led him to state: "If the development of the endoskeletal hard tissues in the lower Gnathostomes in general is taken into consideration, the conclusion suggests itself that calcification of cartilage and ossification of connective tissue are collateral processes." Calcified cartilage has been iden- 
tified in the skeleton of Eriptychius, one of the most primitive heterostracan agnathans known from the fossil record (Orvig, '51; Denison, '67; Halstead, '69, '73, '74; Hall, '75). Likewise calcified cartilage formed part of the endoskeleton in the earliest gnathostomes, the Acanthodii and the Placodermi (Holmgren, '42; Orvig, '51, '67; Moy-Thomas and Miles, '71). Calcified cartilage persisted in fossil and living elasmobranchs and holocephalans (Orvig, '51; Schaeffer and Williams, '77). According to Orvig this type of tissue occurs also in some Teleostomi and even in some Amphibia. In mammals calcification of cartilage precedes ossification in limb articular cartilages, growth plate cartilages and mandibular condyle cartilages.

The problem of how calcified cartilage and endoskeletal bone evolved together or separately in the phylogeny of the vertebrate endoskeleton is fundamentally the question of how differentiation of the pluripotent cells of skeletogenous connective tissue is regulated. In the development of dermal bone or dentine, as well as in perichondral or endochondral bone, fibroblasts or mesenchymal precursor cells transform directly into scleroblasts. In the development of calcified cartilage, however, perichondrial cells first develop as chondroblasts which secrete a hyaline matrix; secondarily these cells become scleroblasts. The odontode theory of the origin of dermal bone and dentine (Orvig, '67, '77) is explainable on the basis of direct conversion of dermal fibroblasts to osteoblasts or odontoblasts. According to Holmgren's delamination theory (Holmgren, '42; Jarvik, '59), endoskeletal bone arose by delamination from dermal bone, but Patterson ('77) believes that dermal and endoskeletal bone development have probably been separate processes throughout the phylogeny of the vertebrates.

Orvig ('51) has described the endoskeleton of a variety of placoderms and some acanthodians as consisting of a layer of perichondral bone underlain by globular calcified cartilage. He considers this association of bone and calcified cartilage as a primitive gnathostome characteristic. According to this concept, modern elasmobranchs may be regarded as fishes which have undergone regression of endoskeletal bone development while retaining calcified cartilage as an endoskeletal characteristic. Conversely, teleostomes may be considered fishes which have retained endoskeletal bone and undergone regression of calcified cartilage. Although the evolutionary relationships of the most primitive gnathostomes, the Acanthodii, have been in question (Stahl, '74), Jarvik ('77) now believes that they should be considered primitive elasmobranchs, because of their many similarities to the Selachii, particularly notidanid and squaloid sharks. Endoskeletal characteristics of the acanthodians thus assume importance for interpreting evolution of the endoskeleton in modern elasmobranchs.

This much is certain from the histological analysis of fossils: calcified cartilage is a primitive vertebrate hard tissue. With respect to this tissue type, therefore, the elasmobranch endoskeleton should be considered primitive rather than embryonic (neotenous) or regressive. Orvig ('51) and more recent authors (Denison, '57; Halstead, '74; Hall, '75; Moss, '77) have presented evidence favoring this interpretation. On the other hand, Ørvig ('51) interprets the organization of calcified cartilage into separate prisms (tesserae) in modern elasmobranchs as a derived or regressive characteristic. He theorizes that tesserae evolved following reduction of the layer of perichondral bone presumed to have been present in the ancestors of modern elasmobranchs. Furthermore, he attributes the evolution of endoskeletal tesserae to "mechanical factors" concerned with supportive functions or to "histologic changes in the ground substance of the cartilage itself." If fragmentation of a preexistent continuous bony layer has been the course of evolution of the elasmobranch endoskeleton, we suggest that elimination of perichondral bone has not proceeded to completion. The cap layers of tesserae can be interpreted as remnants of a once continuous osseous layer.

An alternative to Orvig's theory of osseous regression is that the tesserate pattern of endoskeletal calcification in elasmobranchs is itself a primitive vertebrate characteristic (Denison, '63, '67; Moss, '68a,b, '77; Halstead, '73, '74; Hall, '75). Tesserae were present in the endoskeletons of fossil elasmobranchs and acanthodians (Orvig, '51), and separate blocks of endoskeletal tissue classified as "globular calcified cartilage" have been positively identified in the heterostracan agnathan eriptychiids Eriptychius americanus and Eriptychius orvigi (Denison, '67). A rostral portion of a skull of $E$. americanus examined by Denison contained six endoskeletal calcified elements varying from about $3 \mathrm{~mm}$ to $10 \mathrm{~mm}$ 
in longest dimension. Twelve isolated endoskeletal elements from $E$. orvigi varied from "small" to one $19 \mathrm{~mm}$ long. Endoskeletal elements in these species were of the same order of magnitude as the dermal tesserae overlying them. The endoskeletal tesserae in the shark specimens we have examined (figs. 1-6) were smaller (0.1-0.2 mm in Carcharhinus menisorrah and Negaprion brevirostris; variable up to about $0.5 \mathrm{~mm}$ in Triaenodon obesus). Despite these size differences between eriptychiid and selachian units of endoskeletal calcification, the two types are similar histologically. The "globules" in the calcified cartilage of Eriptychius are undoubtedly calcospherites like those we have described for Carcharhinus. There is evidence of lamination in the matrix of the "wall" surrounding the globular subunits in Eriptychius calcified elements (Denison, '67), and shark tesserae show lamination both peripherally (fig. 10) and in the cap layer (fig. 13).

Variations in size, shape and distribution of calcified cartilaginous elements have certainly evolved during phylogeny, but the tesserate pattern characterizing the endoskeleton of modern Chondrichthyes could be interpreted as a simple variation on the theme of discrete centers of endoskeletal calcification, first originating in the ostracoderms. If the tesserate pattern in elasmobranchs is primitive, then development of a continuous layer of perichondral bone overlying regions of calcified cartilage in the placoderms (Orvig, '51) may be considered an evolutionary advance never achieved by the elasmobranchs. The predominately bony endoskeleton of the teleostomes and higher vertebrates may be interpreted as a still further advance in the direction of enhancement of ossification together with regression of calcified cartilage. It would be instructive to compare the relationships between calcified cartilage and bone in the modern survivors of the paleoniscoids (Stahl, '74), namely, the African bichir Polypterus, the spoonbill Polyodon and the sturgeon Acipenser. It is well known that cartilage is a prominent part of the endoskeleton in these forms, regarded as the most primitive living Actinopterygii, but the extent and pattern of calcification of this cartilage are not well documented (Goodrich, '30).

Whether endochondral tesserae are primitive or derived skeletal adornments in living chondrichthyan fish will continue to be debated (Brown, '75), but we are justified in con- sidering them a very ancient form of vertebrate calcification. It follows that the morphogenesis and histogenesis of the calcified tes. serae in elasmobranchs and holocephalans alive today can teach us how their Ordovician, Silurian and Devonian ancestors must have fortified their internal skeletons. From this knowledge we may also gain insight into the relationships between connective tissue, cartilage and bone as they have evolved in terrestrial vertebrates.

\section{ACKNOWLEDGMENTS}

This is Contribution 564 of the Hawaii Institute of Marine Biology, University of Hawaii, with the support of an institutional grant from the U.S. Department of Energy for operation of the Mid-Pacific Marine Laboratory, Enewetak Atoll, Marshall Islands. The research was initiated during periods of study at the MPML, Enewetak, in 1965 and 1972 while the senior author was on sabbatical leaves at the University of Hawaii. Grants from the National Science Foundation (GB 4317) and the U.S. Public Health Service (AM 13745) and from the University of Michigan Cancer Research Institute (Project 102 and SOMN RPP31) have supported continuation of the investigation. Special thanks are due to Doctors Robert W. Hiatt, Philip Helfrich, John E. Bardach, William A. Gosline, Fred I. Kamemoto and Richard D. Allen, now or formerly at the University of Hawaii, who provided encouragement and facilities for work there and at Enewetak. We wish to thank Doctor I. Kaufman Arenberg, Department of Otolaryngology, University of Wisconsin, for donating the lemon shark tissue. We are grateful to Research Assistants Betty J. Christian and Richard A. Jacobs for their skill in preparing slides and thin sections for light and electron microscopy. We also thank Doctor Wilbur C. Bigelow and his staff assistants Peggy J. Hollingsworth, Larry F. Allard and A. John Mardinly at the Scanning Electron Microscopy Laboratory, College of Engineering, The University of Michigan, for their instruction and assistance in scanning electron microscopy.

\section{LITERATURE CITED}

Alcock, N. W. 1972 Calcification of cartilage. Clin. Orthop. Rel. Res., 86: 287-311.

Ali, S. Y., and L. Evans 1973 The uptake of ( $\left.{ }^{45} \mathrm{Ca}\right)$ calcium ions by matrix vesicles from calcifying cartilage. Biochem. J., 134: 647-650.

Anderson, H. C. 1969 Vesicles associated with calcifica- 
tion in the matrix of epiphyseal cartilage. J. Cell Biol., 41: 59-72.

1973 Calcium-accumulating vesicles in the intercellular matrix of bone. In: Hard Tissue Growth, Repair and Remineralization. R. F. Sognnaes and J. M. Vaughan, eds. Ciba Foundation Symposium 11 (new series), Assoc. Scient. Publ. (Elsevier-Excerpta MedicaNorth Holland), Amsterdam, pp. 213-246.

Applegate, S. P. 1967 A survey of shark hard parts. In: Sharks, Skates and Rays. P. W. Gilbert, R. F. Mathewson and D. P. Rall, eds. The Johns Hopkins Press, Baltimore, pp. $37-67$.

Bachra, B. N. 1967 Some molecular aspects of tissue calcification (cartilage). Clin. Orthop. Rel. Res., 51: 199-222.

Bargmann, W. 1939 Zur Kenntnis der Knorpelarchitekturen. (Untersuchungen am Skeletsystem von Selachiern). Z. Zellforsch., 29: 405-424.

Bassett, C. A. L. 1964 Environmental and cellular factors regulating osteogenesis. In: Bone Byodynamics. $\mathbf{H}$. M. Frost, ed. Little, Brown and Co,, Boston, pp. 233-244.

Benzer, P. 1944 Morphology of calcification in Squalus acanthias. Copeia, 1944: 217-224.

Berrill, N. J. 1955 The Origin of Vertebrates. Oxford University Press, London.

Bonucei, E. 1970 Fine structure and histochemistry of "calcifying globules" in epiphyseal cartilage. Z. Zellforsch., 103: 192-217.

- 1971 The locus of initial calcification in cartilage and bone. Clin. Orthop. Rel. Res., 78: 108-139.

Bonucci, E., and G. Gherardi 1975 Histochemical and electron microscopic investigations on medullary bone. Cell Tissue Res., 163: 81-97.

Bormuth, H. 1933 Die trajektoriellen Strukturen im Knorpel der Haifische auf Grund von Untersuchungen im polarisierten Lichte. Z. Zellforsch., 17: 767-797.

Boyde, A. 1972 Biological specimen preparation for the scanning microscope - an overview. Scanning Electron Microsc., 1972: 257-264.

Boyde, A., and M. H. Hobdell 1969 Scanning electron microscopy of primary membrane bone. Z. Zellforsch., 99: 98-108.

Boyde, A., and S. J. Jones 1968 Scanning electron microscopy of cementum and Sharpey fibre bone. Z. Zellforsch, 92 : 536-548.

Boyde, A., and E. J. Reith 1969 The pattern of mineralization of rat molar dentine. Z. Zellforsch., 94: 479-486.

Brown, C. H. 1975 Structural Materials in Animals. John Wiley and Sons, New York.

Campo, R. D., and S. J. Phillips 1973 Electron microscopic visualization of proteoglycans and collagen in bovine costal cartilage. Calc. Tissue Res., 13: 83-92.

Daniel, J. F. 1934 The Elasmobranch Fishes. University of California Press, Berkeley.

Denison, R. H. 1963 The early history of the vertebrate skeleton. Clin. Orthop. Rel. Res., 31: 141-152.

1967 Ordovician vertebrates from western United States. Fieldiana, Geol., 16: 131-192.

Dingle, J. T, 1973 Lysosomal enzymes in skeletal tissues. In: Hard Tissue Growth, Repair and Remineralization. R. F. Sognnaes and J. M. Vaughan, eds. Ciba Foundation Symposium 11 (new series), Assoc. Scient. Publ. (Elsevier-Excerpta Medica-North Holland), Amsterdam, pp. 295-313.

Dziewiatkowski, D. D., C. D. Tourtellotte and R. D. Campo 1968 Degradation of protein-polysaccharide (chondromucoprotein) by an enzyme extracted from cartilage. In: The Chemical Physiology of Mucopolysaccharides. G Quintarelli, ed. Little, Brown and Co., Boston, pp. 63-79.

Fleisch, H., and S. Bisaz 1964 Role of collagen, pyrophosphate and pyrophosphatase in calcification. In: Bone and
Tooth. Proc. 1st European Symposium Bone and Tooth Soc. H. J. J. Blackwood, ed. Pergamon Press, Oxford, pp. 249-256.

Fleisch, H., R. Felix, T. Hansen and R. Schenk 1975 Role of organic matrix in calcification. In: Extracellular Matrix Influences on Gene Expression. H. C. Slavkin and R. C. Greulich, eds. Academic Press, New York, pp. 435-440.

Gebhardt, W. 1914 Einige mechanisch interessante Bindegewebsstrukturen. Verh. Anat. Ges., Anat. Anz., Suppl., 46: 205-222.

Glimcher, M. J., and S. M. Krane 1968 The organization and structure of bone and the mechanism of calcification. In: Treatise on Collagen. G. N. Ramachandran, gen. ed. Vol. 2, Part B. Biology of Collagen. B. S. Gould, ed. Academic Press, New York, pp. 67-251.

Goodrich, E. 1930 Studies on the Structure and Development of Vertebrates. Macmillan and Co., London.

Hall, B. K. 1969 Hypoxia and differentiation of cartilage and bone from common germinal cells in vitro. Life Sci., 8 : $553-558$

1970 Cellular differentiation in skeletal tissues. Biol. Rev., Cambridge Phil. Soc., 45: 455-484. 1975 Evolutionary consequences of skeletal differentiation. Amer. Zool., 15: 329-350.

Halstead, L. B. 1969 Calcified tissues in the earliest vertebrates. Calc. Tissue Res., 3: 107-124.

- 1973 The heterostracan fishes. Biol. Rev., Cambridge Phil. Soc., 48: 279-332.

- 1974 Vertebrate Hard Tissues. Springer-Verlag, New York.

Hartman, R. J. 1947 Colloid Chemistry. Second ed. Houghton Mifflin Co., The Riverside Press, Cambridge.

Hasse, J. C. F. 1879 Ueber den Bau und über die Entwickelung des Knorpels bei den Elasmobranchiern. 1-3. Zool. Anz., 2: 325-329, 351-355, 371-374.

Höhling, H. J., R. Kreilos, G. Neubauer and A. Boyde 1971 Electron microscopy and electron microscopical measurements of collagen mineralization in hard tissues. $\mathrm{Z}$. Zellforsch., 122: 36-52.

Höhling, H. J., B. A. Ashton and H. D. Köster 1974 Quan titative electron microscopic investigations of mineral nucleation in collagen. Cell Tissue Res., 148: 11-26.

Holmgren, N. 1942 Studies on the head of fishes. An embyrological, morphological, and phylogenetical study. Part III. The phylogeny of elasmobranch fishes. Acta Zool., 23: 129-261.

Howell, D. S., and J. C. Pita 1976 Calcification of growth plate cartilage with special reference to studies on micropuncture fluids. Clin. Orthop. Rel. Res., 118: 208-229.

Howell, D. S., J. C. Pita, J. F. Marquez and R. A. Gatter 1969 Demonstration of macromolecular inhibitor (s) of calcification and nucleational factor(s) in fluid from calcifying sites in cartilage. J. Clin. Invest., 48: 630-641. Jarvik, E. 1959 Dermal fin-rays and Holmgren's principle of delamination. K. Svenska Vetensk. Akad. Handl., 4: 1 -51.

- 1977 The systematic position of acanthodian fishes. In: Problems in Vertebrate Evolution. S. M. Andrews, R. S. Miles and A. D. Walker, eds. Linnean Soc. Symposium Series 4, Academic Press, New York, pp. 199-225.

Jones, S. J., and A. Boyde 1974 The organization and gross mineralization patterns of the collagen fibres in Sharpey fibre bone. Cell Tissue Res., 148: 83-96.

Kemp, N. E. 1977 Calcification of the endoskeleton in elasmobranchs. Amer. Zool., 17: 932 (Abstract)

Kemp, N. E., and J. H. Park 1974 Ultrastructure of the enamel layer in developing teeth of the shark Carcharhinus menisorrah. Archs. Oral Biol., 19: 633-644.

Kemp, N. E., and S. J. Smith 1976 Scanning electron mi 
croscopy of crystalline pattern in shark scales, teeth and calcified portions of skeleton. Amer. Zool., 16: 183 (Abstract).

Kemp, N. E., S. J. Smith and R. A. Jacobs 1975 Ultrastructure of calcified jaw tesserae in the lemon shark Negaprion brevirostris. Amer. Zool., 15: 329 (Abstract).

Kogayashi, S. 1971 Acid mucopolysaccharides in calcified tissues. Int. Rev. Cytol., 30: 257-371.

Kuettner, K. E., J. C. Pita, D. S. Howell, N. Sorgente and R. Eisenstein 1975 Regulation of epiphyseal cartilage maturation. In: Extracellular Matrix Influences on Gene Expression. H. C. Slavkin and R. C. Gruelich, eds. Academic Press, New York, pp. 435-440.

Kyle, H. M. 1927 Über die Entstehung und Bildung der Hartsubstanz bei Fischen. Z. Mikr. Anat. Forsch., 9: 317-384

Lohmander, S., and A. Hjerpe 1975 Proteoglycans of mineralizing rib and epiphyseal cartilage. Biochim. Biophys. Acta, 404: 93-109.

MacConaill, M. A. 1973 Calcospheritic calcification of cartilage. J. Anat., 115: 23-27.

Majeska, R. J., and R. E. Wuthier 1975 Studies on matrix vesicles isolated from chick epiphyseal cartilage: associa tion of pyrophosphatase and ATPase activities with alkaline phosphatase. Biochim. Biophys. Acta, 391: 51-60.

Mathews, J. L. 1972 Evolution of mineralizing tissues. In: The Comparative Molecular Biology of Extracellular Matrices. H. C. Slavkin, ed. Academic Press, New York, pp. 155-162.

Mathews, M. B. 1966 The molecular evolution of cartilage. Clin. Orthop. Rel. Res., 48: 267-283.

1968 Molecular evolution of connective tissue. In: Biology of the Mouth. P. Person, ed. Publ. No. 89, Am Assoc. Adv. Sci., Washington, D. C., pp. 189-236.

1975 Connective Tissue: Macromolecular Structure and Evolution. Springer-Verlag, New York.

Matukas, V. J., and G. A. Krikos 1968 Evidence for changes in protein polysaccharide associated with the onset of calcification in cartilage. J. Cell Biol., 39: 43-48.

Meikle, M. C. 1975 The influence of function on chondrogenesis at the epiphyseal cartilage of a growing long bone. Anat. Rec., 182: 387.400 .

Moss, M. L. 1964 The phylogeny of mineralized tissues. Int. Rev. Gen. Exp. Zool., 1: 297-331.

1968a The origin of vertebrate calcified tissues. In: Current Problems of Lower Vertebrate Phylogeny. T. Ørvig, ed. Nobel Symposium 4, Almquist \& Wiksell, Stockholm; Interscience Publ., New York, pp. 359-371. $1968 \mathrm{~b}$ Bone, dentin and enamel and the evolution of vertebrates. In: Biology of the Mouth. P. Person, ed. Publ. No. 89, Am. Assoc. Adv. Sci., Washington, D.C., pp. 37-65.

- 1970 Enamel and bone in shark teeth: with a note on fibrous enamel in fishes. Acta Anat., 77: 161-187. 1977 Skeletal tissues in sharks. Am. Zool., 17 $335-342$.

Moy-Thomas, J. A., and R. S. Miles 1971 Paleozoic Fishes. Second ed. W. B. Saunders Co., Philadelphia.

Orvig, T. 1951 Histologic studies of placoderms and fossil elasmobranchs. I. The endoskeleton, with remarks on the hard tissues of lower vertebrates in general. Ark. Zool., 2: 321-454.

Zool., 1967 Phylogeny of tooth tissues. Evolution of some calcified tissues in early vertebrates. In: Structural and Chemical Organization of Teeth. Vol. 1. A. E. W. Miles, ed. Academic Press, New York, pp. 45-110.

1977 A survey of odontodes ('dermal teeth') from developmental, structural, functional and phyletic points of view. In: Problems of Vertebrate Evolution. S. M. Andrews, R. S. Miles and A. D. Walker, eds. Linnean Soc. Symposium Series 4, Academic Press, New York, pp. 53-75.

Patterson, C. 1977 Cartilage bones, dermal bones and membrane bones, or the exoskeleton versus the endoskeleton. In: Problems in Vertebrate Evolution. S. M. Andrews, R. S. Miles and A. D. Walker, eds. Linnean Soc. Symposium Series 4, Academic Press, New York, pp. 77-121.

Peresz, N. S., H. C. Anderson and S. W. Sajdera 1974 The lipids of matrix vesicles from bovine epiphyseal cartilage. Calc. Tissue Res., 14: 275-281.

Pita, J. C., L. A. Cuervo, J. E. Madruga, F. J. Muller and D. S. Howell 1970 Evidence for a role of protein polysaccharides in regulation of mineral phase separation in calcifying cartilage. J. Clin. Invest., 49: 2188-2197.

Ridewood, W. G. 1921 On the calcification of the vertebral centra in sharks and rays. Phil. Trans. Roy. Soc. Lon. don (B), 210: 311-407.

Romer, A. S. 1942 Cartilage an embyronic adaptation. Amer. Naturalist, 76: 394-404.

1945 Vertebrate Paleontology. The University of Chicago Press, Chicago.

Röse, C. R. 1898 Ueber die verschiedenen Abänderungen der Hartgewebe bei niederen Wirbeltiere. Anat. Anz., 14: 21-31, 33-69.

Roth, W. 1911 Beiträge zur Kenntnis der Strukturverhältnisse des Selachier-Knorpels. Morph. Jahrb., 42: $485 \cdot 555$.

Sayegh, F. S., G. S. Solomon and R. W. Davis 1974 Ultrastructure of intracellular mineralization in the deer's antler. Clin. Orthop. Rel. Res., 99: 267-284.

Schaeffer, B., and M. Williams 1977 Relationships of fossil and living elasmobranchs. Amer. Zool., 17: 293-302.

Schmidt, W. J. 1947 Über homogene und sphäritische Verkalkung bei den verschiedenen Arten des Knochengewebes. Naturwiss., 34: 273-277.

1952 Über die Verkalkung des Knorpelgewebes der Haie. Z. Zellforsch., 37: 377-388.

Shepard, N., and N. Mitchell 1976 Simultaneous localization of proteoglycan by light and electron microscopy using toluidine blue $\mathrm{O}$. A study of epiphyseal cartilage. $J$. Histochem. Cytochem., 24: 621-629.

Silbermann, M., and J. Frommer 1974 Initial locus of calcification in chondrocytes. Clin. Orthop. Rel. Res., 98: 288-293.

Simon, D. R., I. Berman and D. S. Howell 1973 Relationship of extracellular matrix vesicles to calcification in normal and healing rachitic epiphyseal cartilage. Anat. Rec., 176: $167-179$.

Stahl, B. J. 1974 Vertebrate History: Problems in Evolution. McGraw-Hill Book Co, New York.

Tarlo, L. B. H. 1967 The tessellated pattern of dermal armor in the Heterostraci. J. Linn. Soc. (Zool.), 47: 45-54.

Thyberg, J. 1974 Electron microscopic studies on the initial phases of calcification in guinea pig epiphyseal car. tilage. J. Ultrastruct. Res., 46: 206-218.

Travis, D. F. 1968 Comparative ultrastructure and organization of inorganic crystals and organic matrices of mineralized tissues. In: Biology of the Mouth. P. Person, ed. Publ. No. 89, Am. Assoc. Adv. Sci., Washington, D. C., pp. 237-297.

Tretjakoff, D. 1926 Die funktonelle Struktur der Chordascheiden und der Wirbel bei Zyklostomen und Fischen. Z. Zellforsch., 4: 266-312.

Urist, M. 1961 Calcium and phosphorus in the blood and skeleton of the Elasmobranchii. Endocrinol., 69: 778-801. 1970 Induction and differentiation of cartilage 
and bone cells. In: Cell Differentiation. O. A. Schjeide and J. deVellis, eds. Van Nostrand Publ. Co., Amsterdam, pp. 504-528.

Urist, M. R., H. Iwata, S. D. Boyd and P. L. Ceccotti 1974 Observations implicating an extracellular enzymic mechanism of control of bone morphogenesis. J. Histochem. Cytochem., 22: 88-103.

Weidenreich, F. 1922 Über die Beziehungen zwischen Muskelapparat und Knochen und den Character des Knochengewebes. Verh. Anat. Ges. 31, Anat. Anz., Suppl., 55: 28-53.

1923 Über den Begriff "Knochen" und die Beziehungen des Knochengewebes zu Bindegewebe und Knorpel. Verh. Anat. Ges., 32, Anat. Anz., Suppl. 57: 138- 153.

1930 Das Knochengewebe. In: Handbuch der mikroskopischen Anatomie des Menschen. Vol. II, 2. W. von Mollendorf, ed. Julius Springer, Berlin, pp. 391-520. Westoll, T. S. 1967 Radotina and other tesserate fishes. J. Linn. Soc. (Zool.), 47; 83-98.

Woodward, A. S. 1889 Catalogue of the Fossil Fishes in the British Museum. Part I. The Elasmobranchii. British Museum (Natural History), London.

Wurmbach, H. 1932 Das Wachstum des Selachierwir. bels und seiner Gewebe. Zool. Jahrb. (Abt. Anat. Ont. Tiere), 55: 1-136.

Wurthier, R. E. 1975 Lipid composition of isolated epiphyseal cartilage cells, membranes and matrix vesicles. Biochim. Biophys. Acta, 409: 128-143.

Yanagisawa, T. 1975 Electron-microscopic study of matrix vesicles and their alkaline-phosphate activity. Bull. Tokyo Dent. Coll., 16: 109-118. 
PLATE 1

EXPLANATION OF FIGURES

1 Scanning electron micrograph of tesserae (T) of a cylindrical portion of a hemal arch from a vertebra of Carcharhinus menisorrah. The central region of hyaline cartilage is devoid of tesserae which were lost because treatment with Clorox was continued long enough to separate them from the cartilage in which they were embedded. Drying of the specimen has caused widening of the natural distances between tesserae (arrow). Scale $100 \mu \mathrm{m} . \times 80$

2 Tesserae ( $\mathrm{T}$ ) of a portion of a gill arch from C. menisorrah. Tesserae at the top are oriented in lateral view; those below show their exposed outer surfaces. Between upper and lower groups of tesserae is a region from which tesserae fell off during Clorox treatment. Those just below this denuded zone are well separated (arrow), partly as a result of contraction of inner hyaline cartilage during dehydration. The tightly packed tesserae at the bottom of the picture are separated by perforations normally occupied by uncalcified tissue. Scale $100 \mu \mathrm{m} . \times 50$.

3 Tesserae (T) of portions of three adjoining neural arches of vertebrae of $C$. menisorrah. The tesserae here are relatively small in diameter and thinner than those shown in other locations (figs. $1,2,4,5$ ). Scale 100 $\mu \mathrm{m} . \times 50$.

4 Tesserae (T) of jaw of Triaenodon obesus. They are more irregular in shape, tend to be larger, and exhibit more fusion of adjoining tesserae than do those of Carcharhinus or Negaprion (figs. 1-3, 5). Wide gap (arrow) is an artifact caused by dehydration. Scale $100 \mu \mathrm{m} . \times 65$. 

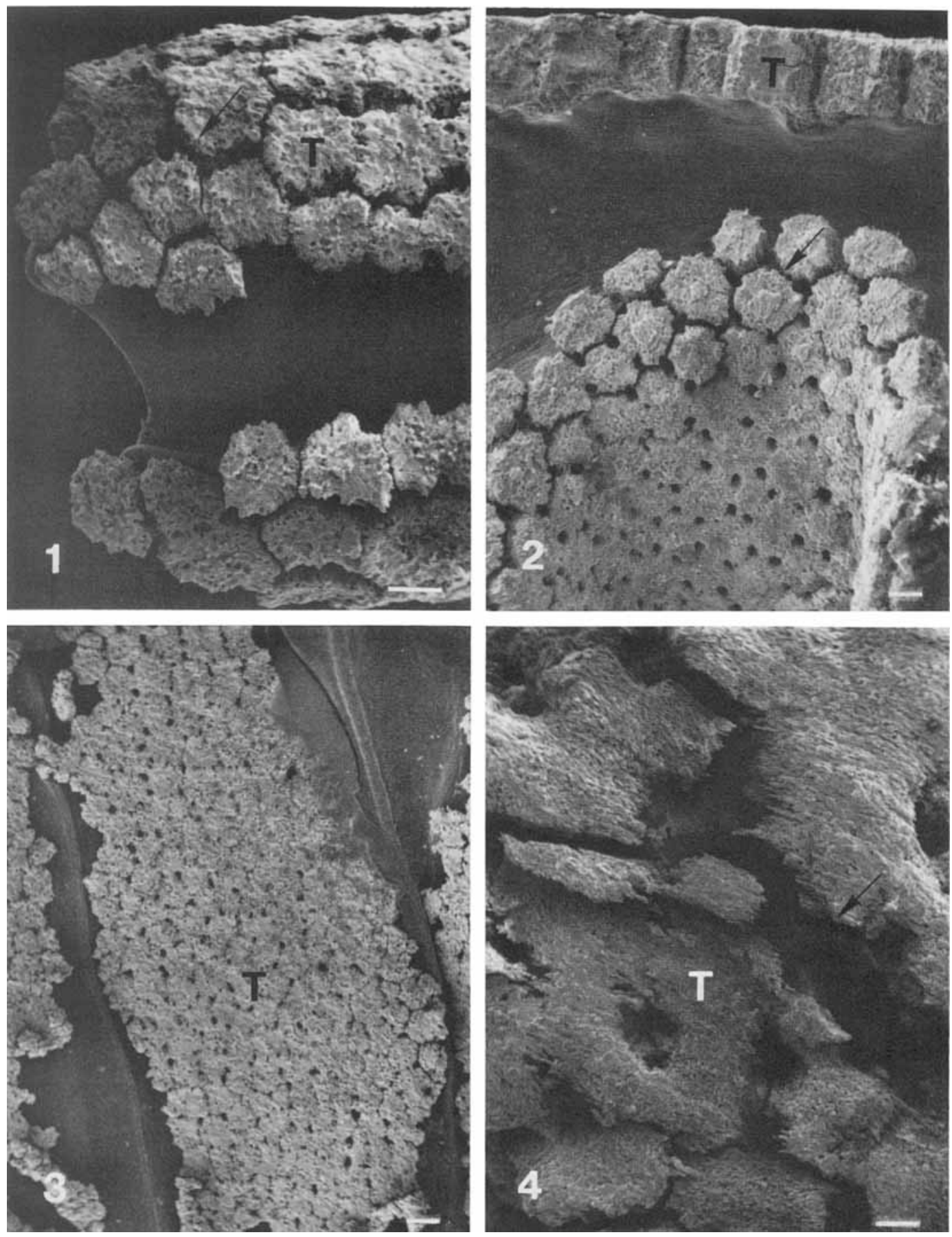


\section{PLATE 2}

\section{EXPLANATION OF FIGURES}

5 Tesserae of a portion of the jaw skeleton of Negaprion brevirostris, showing their localization on the surface of the hyaline cartilage (C) in the interior of the jaw. Spaces between tesserae ( $T$ ) have widened as an artifact of dehydration. Scale 100 $\mu \mathrm{m} . \times 80$.

6 Tesserae of jaw skeleton of $N$. brevirostris, tilted to show rough outer surface (TOS) and the lateral surface (TLS). Scale $100 \mu \mathrm{m} . \times 240$.

7 Enlarged view of rough outer surface of portion of a jaw tessera of $N$. brevirostris, showing numerous relatively small spherulitic masses (sm) and also projections composed of aligned hydroxyapatite crystallites (cr). Scale $10 \mu \mathrm{m} . \times 2,000$.

8 Rough outer surface of portion of a jaw tessera of Carcharhinus menisorrah similar to that of figure 7 . Here the elevations containing aligned hydroxyapatite crystallites (cr) project prominently above the level of spherulitic masses (sm). Scale $10 \mu \mathrm{m} . \times 2,000$. 

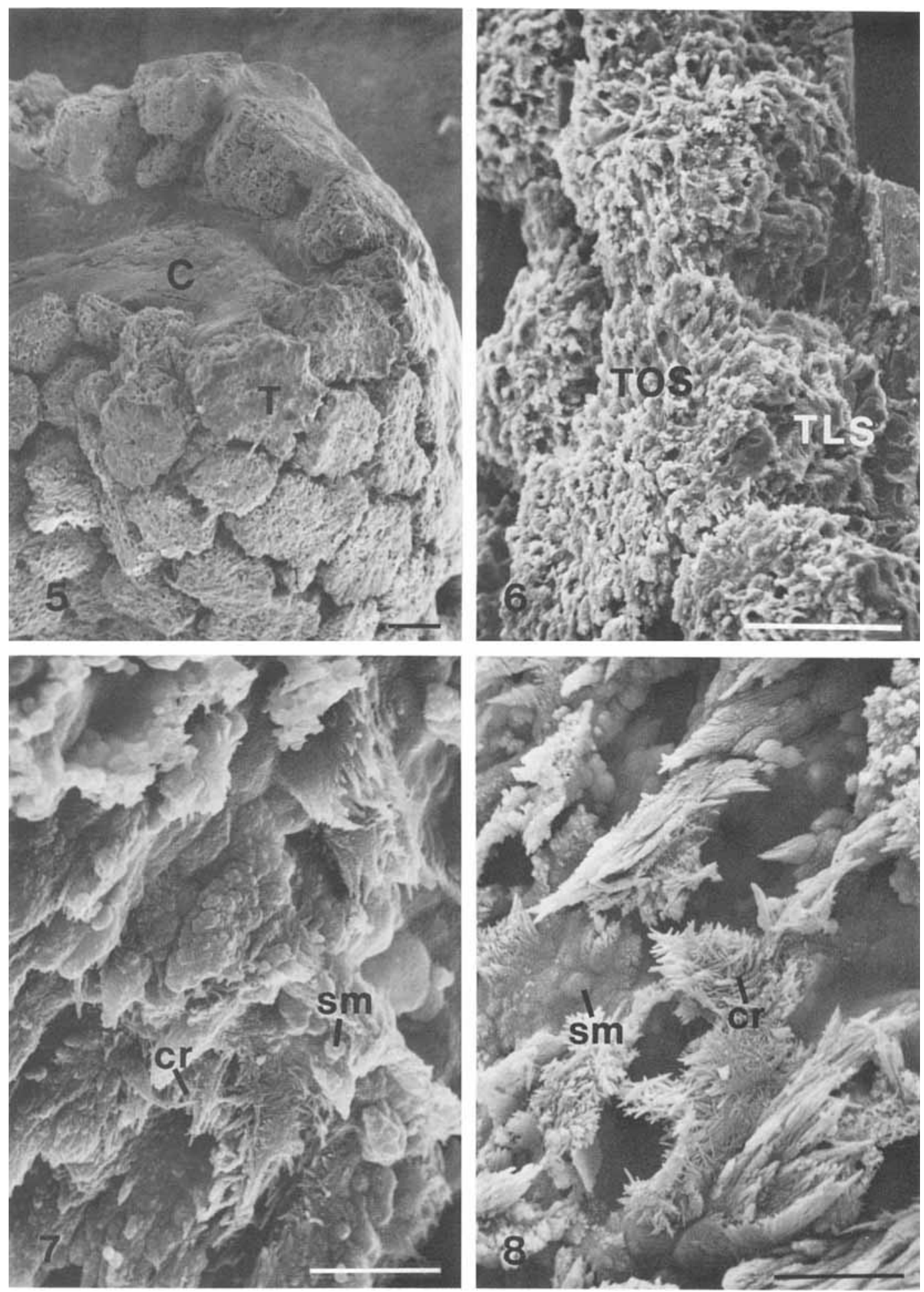
PLATE 3

\section{EXPLANATION OF FIGURES}

9 Portions of two adjoining tesserae in the jaw skeleton of Carcharhinus menisor. rah. Upper one shows rough outer surface (TOS) and lateral surface (TLS). Lower tessera has been fractured along an interlaminar plane parallel to the outer surface and shows the relatively smooth face of a sub-surface lamella interrupted by spaces presumably occupied by cells in life. Scale $10 \mu \mathrm{m} . \times 325$.

10 Lateral (TLS) and inner (TIS) surfaces of portion of a tessera of C. menisorrah. Note that the lateral surface appears laminar (arrow) and shows openings for cells or uncalcified matrix. Inner surface, normally adjacent to cartilage, is coated with spherulitic masses (calcospherites) of variable size. Scale $10 \mu \mathrm{m} . \times 600$.

11 Inner surface of portion of a tessera of C. menisorrah, showing abundance of calcospherites and their pattern of fusion to one another and to the body of the tessera. Scale $10 \mu \mathrm{m} . \times 600$.

12 Enlarged view of inner surface of a tessera of $C$. menisorrah. Globules of various sizes are fused to one another and to the tesseral body. Aligned hydroxyapatite crystallites such as those on the outer side of the tessera (figs. 7,8 ) are absent from this surface. Scale $10 \mu \mathrm{m} . \times 2,000$. 

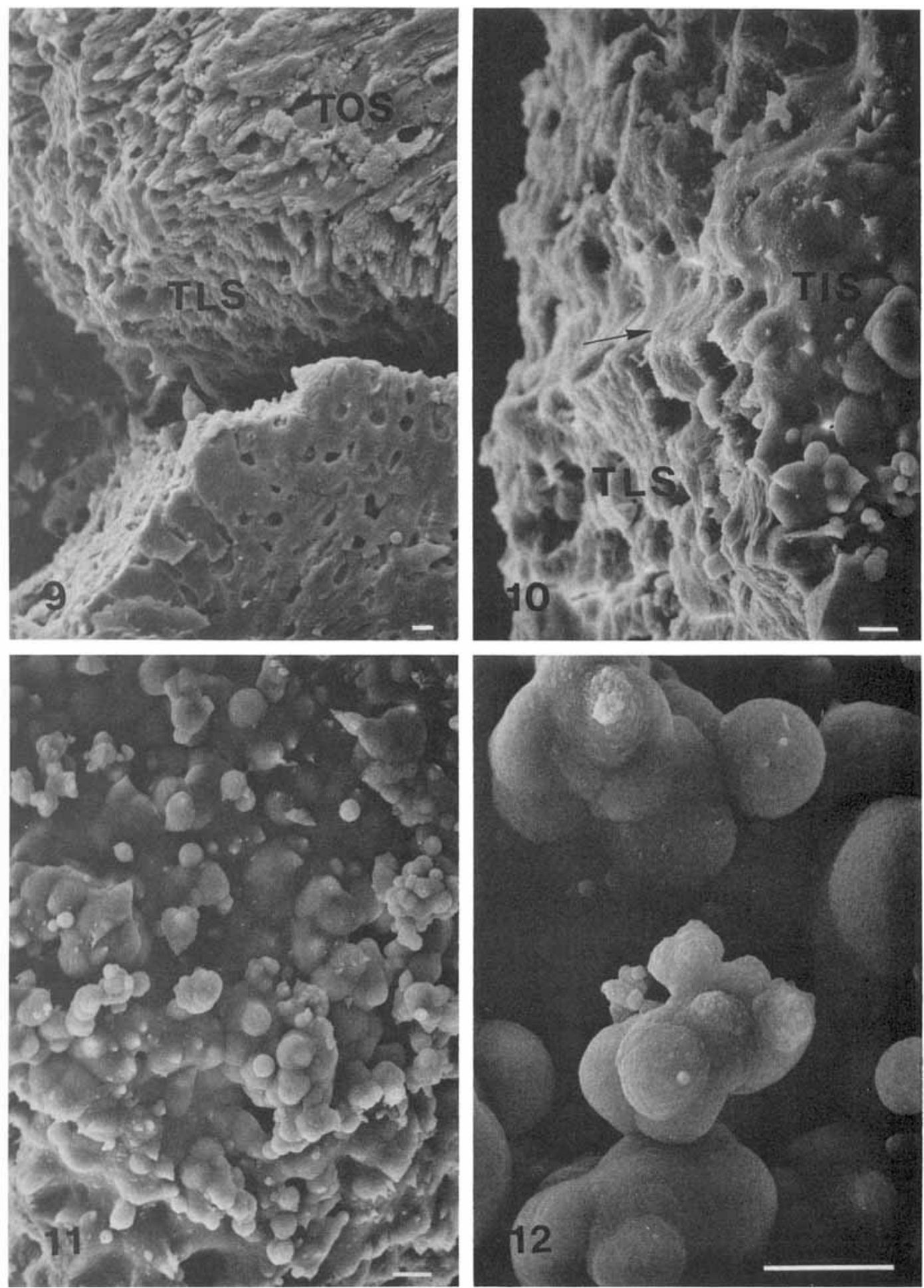


\section{PLATE 4}

\section{EXPLANATION OF FIGURES}

13 Photomicrograph of a tessera ( $\mathrm{T}$ ) and edges of two adjoining tesserae on the surface of the jaw of Carcharhinus menisorrah, showing relationship to underlying hyaline cartilage (C) of the interior of the jaw, to connective tissue overlying the tesserae, and to the basal plate of a calcified tooth (TO) above the jaw. Uncalcified cartilage separates the lateral margins of tesserae. Below the tooth is a sub-odontal (SO) layer of connective tissue containing large collagen fibers which penetrate the bone of the basal plate. Overlying the jaw is a supra-tesseral (ST) layer of connective tissue. A large collagen fiber, like a Sharpey fiber of bone (arrow), penetrates the cap of the tessera. Hematoxylin and eosin. $\times 220$.

14 Enlarged view of the basal plate of a tooth (TO) and underlying sub-odontal connective tissue. Connec tive tissue fills branches of pulp (P) within the tooth. Large collagen fibers like Sharpey fibers penetrate the base of the tooth. Some scleroblastic cells derived from sub-odontal connective tissue have become entrapped within the basal plate (arrow). Hematoxylin and eosin. $\times 360$.

15 Enlarged view of the outer portion of the tessera seen in figure 13. The body (TB), composed of calcified cartilage, is lighter than the cap (TC) because of their different staining reactions with hematoxylin and eosin (see text). Cells in the body are round or oval, while those of the cap tend to be elongated parallel to the surface like those of perichondrial fibroblasts. A large, Sharpey-like collagen fiber (arrow) penetrates deeply in to the cap zone. Hematoxylin and eosin. $\times 300$.

16 Enlarged view of the internal portion of a tessera $(T)$ bordering its bed of hyaline cartilage (C). Waves and rings of Liesegang, basophilic contour lines in the tesseral matrix, are prominent (arrow). Within the cartilage a broader wave pattern is apparent. Hematoxylin and eosin. $\times 360$. 

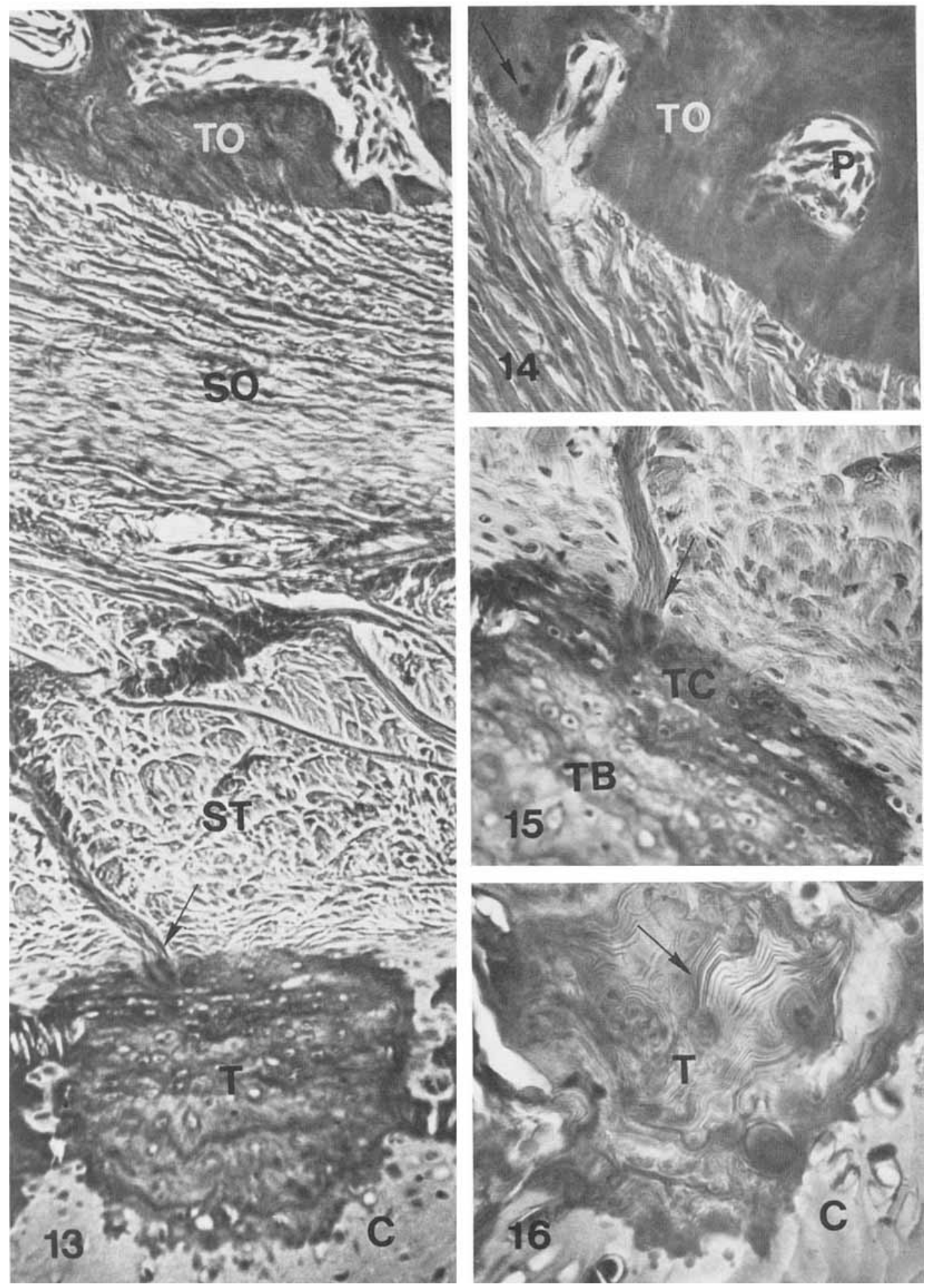
PLATE 5

EXPLANATION OF FIGURES

17 Transmission electron micrograph of chondrocytes (CC), uncalcified matrix surrounding chondrocytes $(\mathrm{CM})$, and perichondrial matrix $(\mathrm{P})$ at the outer border of the jaw cartilage in Negaprion brevirostris. Light, unstained collagen fibrils in the perichondrium are interspersed with dark-staining ground substance. The cartilage matrix contains no coarse collagen fibrils but is mottled with dark proteoglycan granules. Scale $1 \mu \mathrm{m} . \times 12,075$.

18 Chondrocyte (CC), capsular zone of uncalcified matrix (CM), and adjoining miner alized (calcified) matrix (M) near the outer surface of a tessera in $N$. brevirostris. Note that new mineralization toward the outer surface (arrow) appears to be oriented in relation to the ralatively coarse collagen fibrils (co) present in the subperichondrial matrix. Scale $1 \mu \mathrm{m}$. $\times 16,180$. 

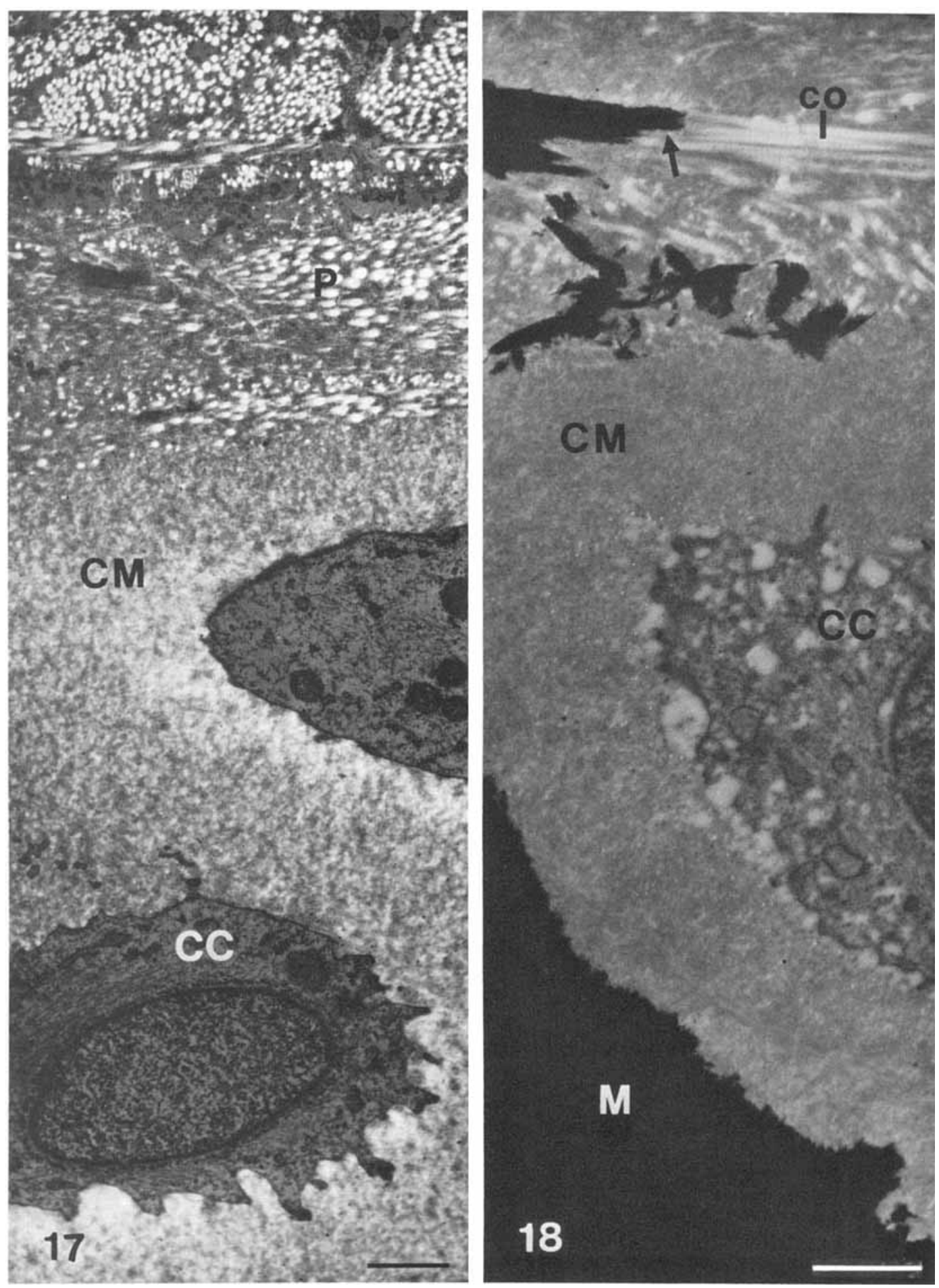
PLATE 6

EXPLANATION OF FIGURE

19 Portions of two chondrocytes (CC), surrounding capsular zones of uncalcified matrix (CM), and zone of new mineralization (M) of matrix separating them near the outer surface of a tessera of Negaprion brevirostris. As shown also in figure 18, calcification is localized in matrix occupied by coarse collagen fibrils. Sites of early calcification are either rounded or elongate (coarse arrow), apparently in relation to the plane of section of the collagen fibrils (co) with which they are associated. Matrix vesicles derived from chondrocytes (fine arrow) may be sites of early calcification, but capsular zones around the cells illustrated here are largely uncalcified. Scale $1 \mu \mathrm{m} . \times 15,200$. 


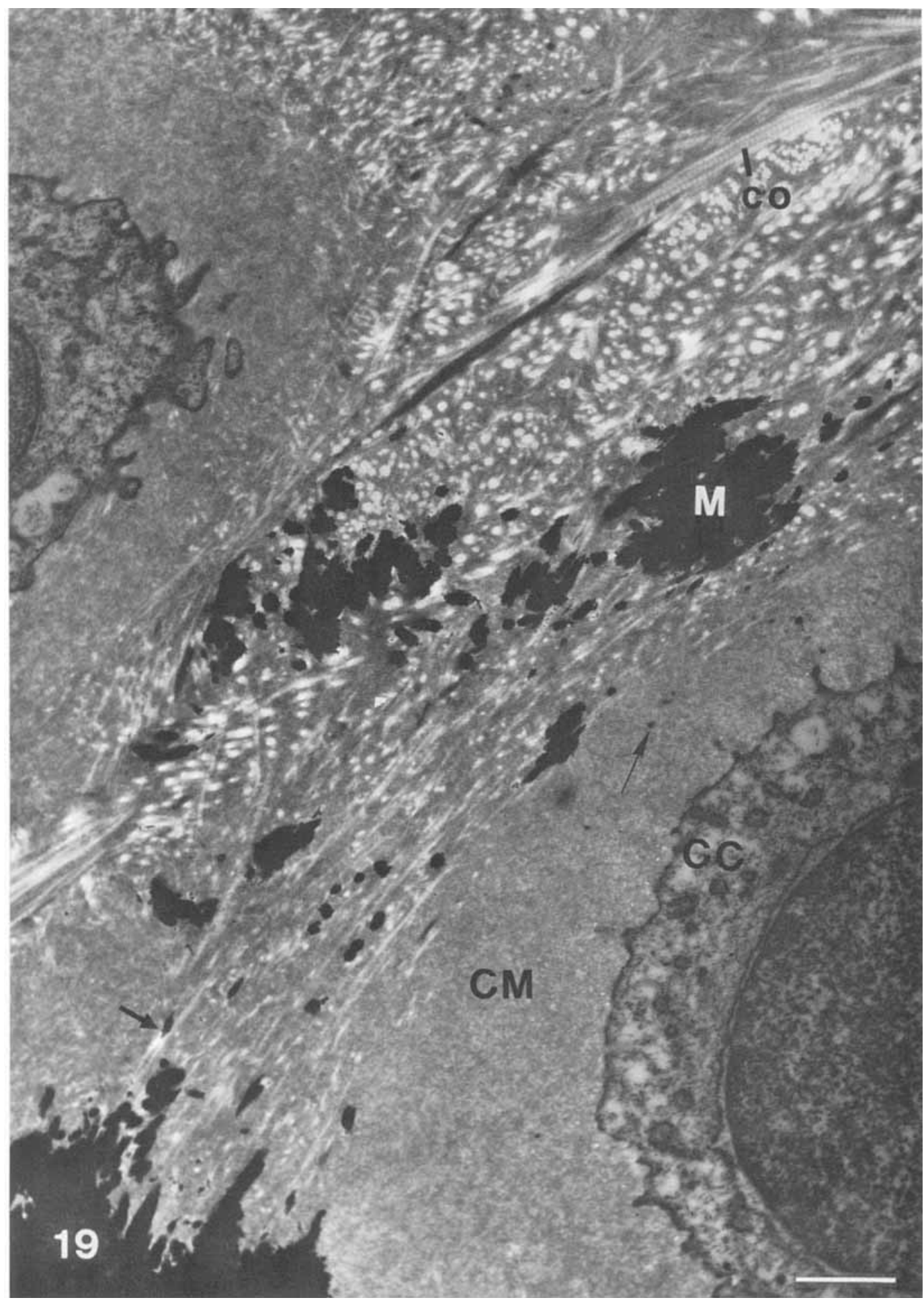




\section{PLATE 7}

\section{EXPLANATION OF FIGURES}

20 Chondrocyte (CC) of Negaprion brevirostris which is nearly surrounded by heavily calcified matrix (M), but which retains a capsular zone of uncalcified matrix (CM). The nucleus $(N)$ of the cell shows no sign of pycnosis, and the cytoplasm is like that of a healthy cell. A spherulitic calcifying mass not yet fused to the main mass of the tessera is seen at upper left. Scale $1 \mu \mathrm{m} . \times 22,350$.

21 A chondrocyte (CC) of $N$. brevirostris completely enclosed by calcified matrix (M). Nucleus $(N)$ and vesicles of endoplasmic reticulum in cytoplasm indicate that the cell is viable. A thin capsular zone of uncalcified cartilage (CM) remains around some parts of the cell. Hydroxyapatite crystallites at the mineralizing front are small and elongate. Scale $1 \mu \mathrm{m} . \times 36,155$ 

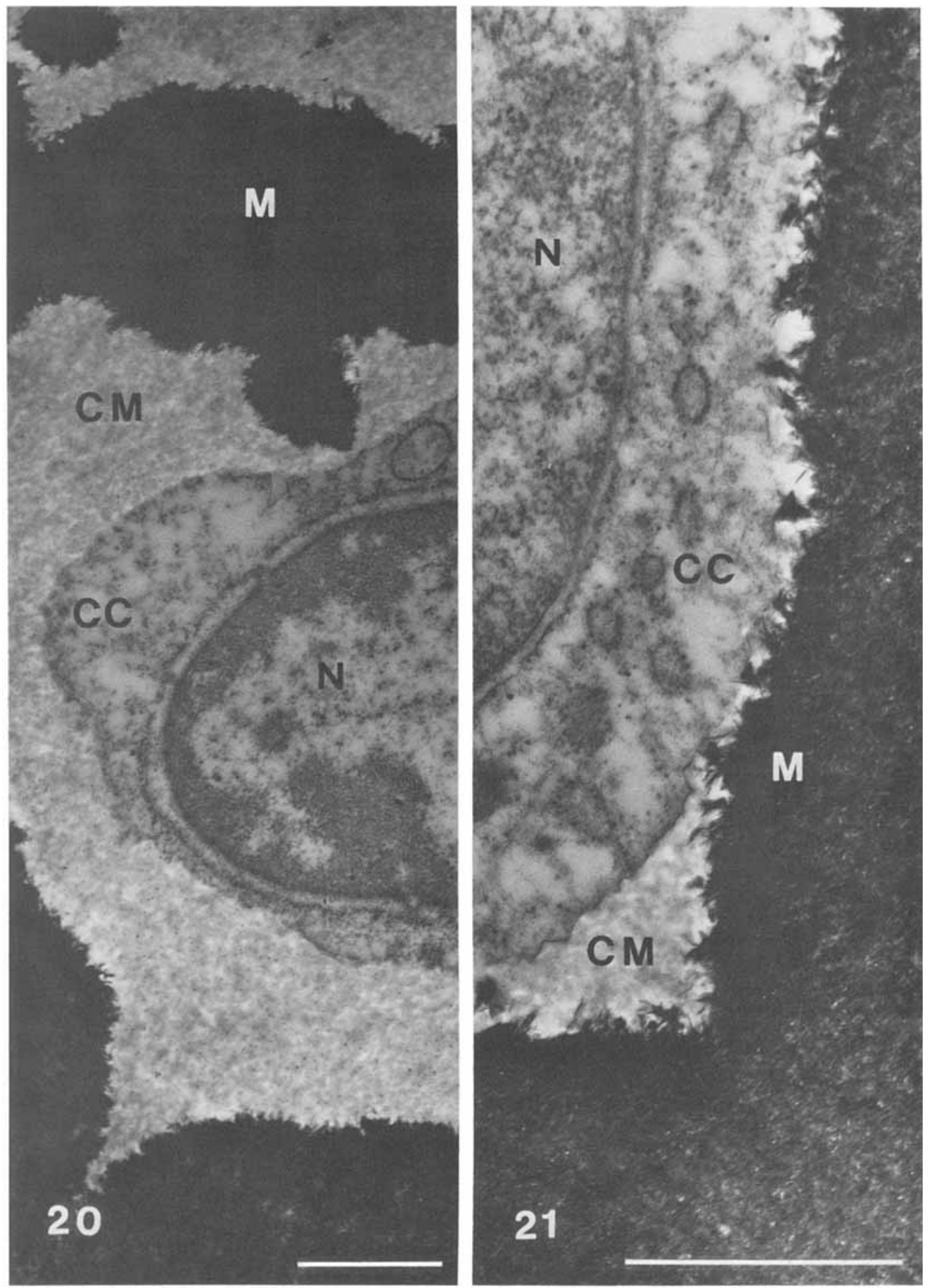